\title{
FLOWER COLOUR IN LOCHNERA ROSEA
}

\author{
N. W. SIMMONDS \\ Regional Research Centre, Imperial College of Tropical Agriculture, \\ Trinidad, W.I.
}

Received 1 7.vii.59

\section{INTRODUCTION}

IN a survey of anthocyanins of tropical plants, Forsyth and Simmonds (I954) found that the flowers of periwinkle, Lochnera (Vinca) rosea $(L$. Reichenb. (Apocynaceæ), contained a pigment of which the aglycone corresponded with none of the common types recognised in other plants. Later studies (Forsyth and Simmonds, I957) showed that the anthocyanidin was trimethyl delphinidin and corresponded in its properties with hirsutidin, a pigment which has otherwise been recognised only in the Primulaceæ (Harborne, 1958). The periwinkle is widely cultivated and escaped in the tropics and is favourable material for genetical and chemical studies of pigmentation. Genetical investigations were begun in 1955 and carried on in collaboration with two post-graduate students at this institution (Waitt, r956; Andrews, 1957). It is the purpose of this paper to report the genetical results obtained to date.

\section{METHODS}

Foundation stocks were obtained from local gardens and were at first vegetatively propagated by cuttings, which are easily rooted in a sand propagator. The mature plants are vigorous perennials with a potential life of several years, though often lost to the attack of root fungi or a (yet unidentified) virus. The seed is small and the young seedlings delicate; damping-off is peculiarly troublesome in the early stages. The plants take about to weeks to flower under tropical conditions and thrive best under high light intensity and light watering. They can be crowded in boxes in the open and, though stunted, flower and set fruit well under these conditions.

The morphology of the flower has been described in detail by Boke (1947, I 948 , 1949). The perianth consists of a long, slender tube surmounted by a flat, five-lobed limb; the stamens are epipetalous and cohere in a cluster around the top of the sub-globular stigma, stamens and stigma both being enclosed in a swelling near the top of the corolla tube. The pollen is powdery and the flowers are easily selfed by a means of a blunt needle inserted into the top of the tube (cf. Boke, r 949). Crossing is much more difficult for it is impossible reliably to remove the stamens without also removing a large part of the corolla. Fruit matures in four to five weeks and the follicles must be watched carefully in the later stages for they reach maturity and dehisce with little external sign of change. Seed storage presents certain problems which have not yet been worked out in detail. For short periods of storage, at least, seed should be stored in open air rather than in the desiccator or refrigerator, as the following experiment shows :

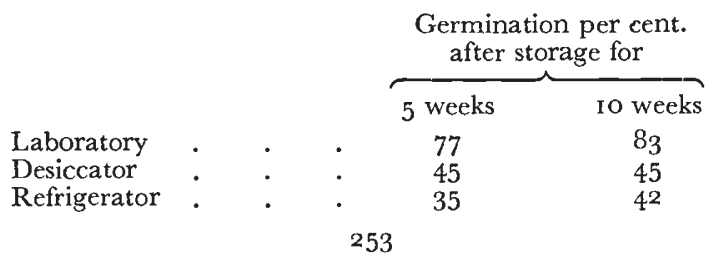




\section{FLOWER COLOUR AND DEVELOPMENT}

Pigment is virtually confined to the limb of the corolla, the tube being green or green with faint reddish streaks in the vicinity of the anthers. On the limb, colour is almost confined to the upper surface and is always most strongly developed towards the bases of the lobes, at the point of junction with the tube; at this point the centre of the flower is raised in a distinct annulus with a crater-like centre, the crest of the annulus defining the inner boundary of pigmentation more or less sharply. Pigmentation of the under surface of the corolla limb occurs only in the most strongly coloured (V and $\mathrm{P}$ ) flowers as a faint flush on the left-hand distal margins of the lobes exposed by convolution in the bud.

\section{TABLE I}

Flower colour phenotypes in Lochnera rosea.

Colour descriptions after Wanscher (1953); in the last column, + indicates copigmentation, o none.

The phenotype given in brackets against Fr has not been identified but is presumed to exist

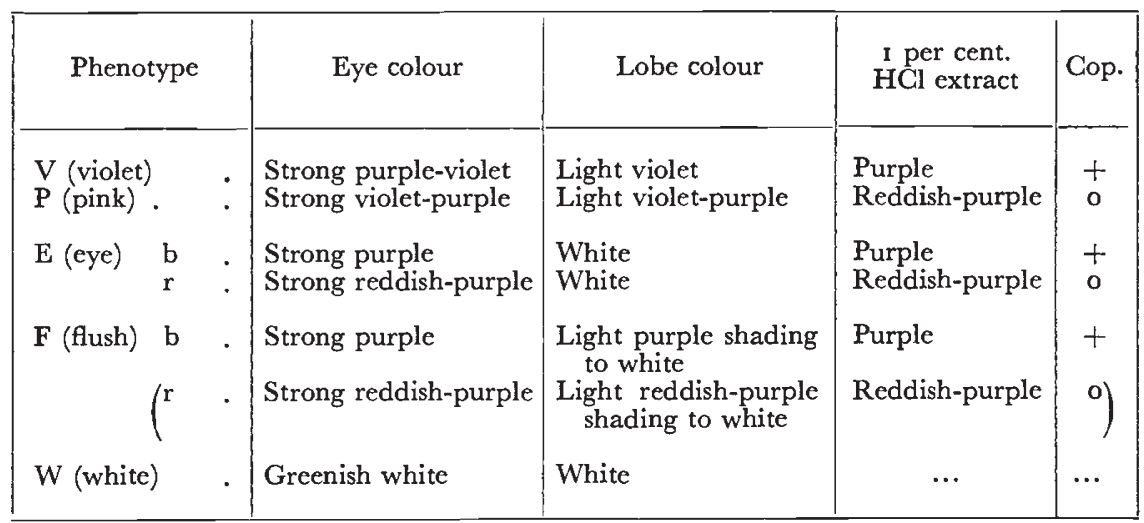

The characters of the various colour forms are summarised in table I. For easy reference, the abbreviations given on the left-hand side of the table are used throughout this paper. Flory (1944), working in the U.S.A., recognised three phenotypes which, from his descriptions and from his mention of forms in the "light pink range", seem to correspond as follows with the types recognised here:

$$
\begin{aligned}
\text { Flory's "Pink" } & =\mathrm{V} \\
\text { "Red eye" } & =\mathrm{E} \\
\text { "White" } & =\mathrm{W}
\end{aligned}
$$

It should be noted that colour matching by different observers of the plants used in different investigations do not always agree exactly and that attempts to correlate Flory's colour descriptions under the Ridgway system with those used here have notbeen successful. Probably personal idiosyncrasy and variability in the material both contribute to these discrepancies. 
Though $\mathrm{V}$ and $\mathrm{P}$ phenotypes are distinct and easily classified, each is somewhat variable as to hue and intensity of colour; no attempt has been made to classify these variations. Pink flowers, though solidly coloured at opening, tend to "break" before falling, sometimes very conspicuously and always more than $\mathrm{V}$ flowers: the pigment fades in angular, sharply bounded patches which spread and coalesce until, when the flower withers, pigment survives only in the eye. This behaviour is perhaps connected with relative instability of noncopigmented anthocyanins. $\mathrm{E}$ and $\mathrm{F}$ flowers present some difficulty

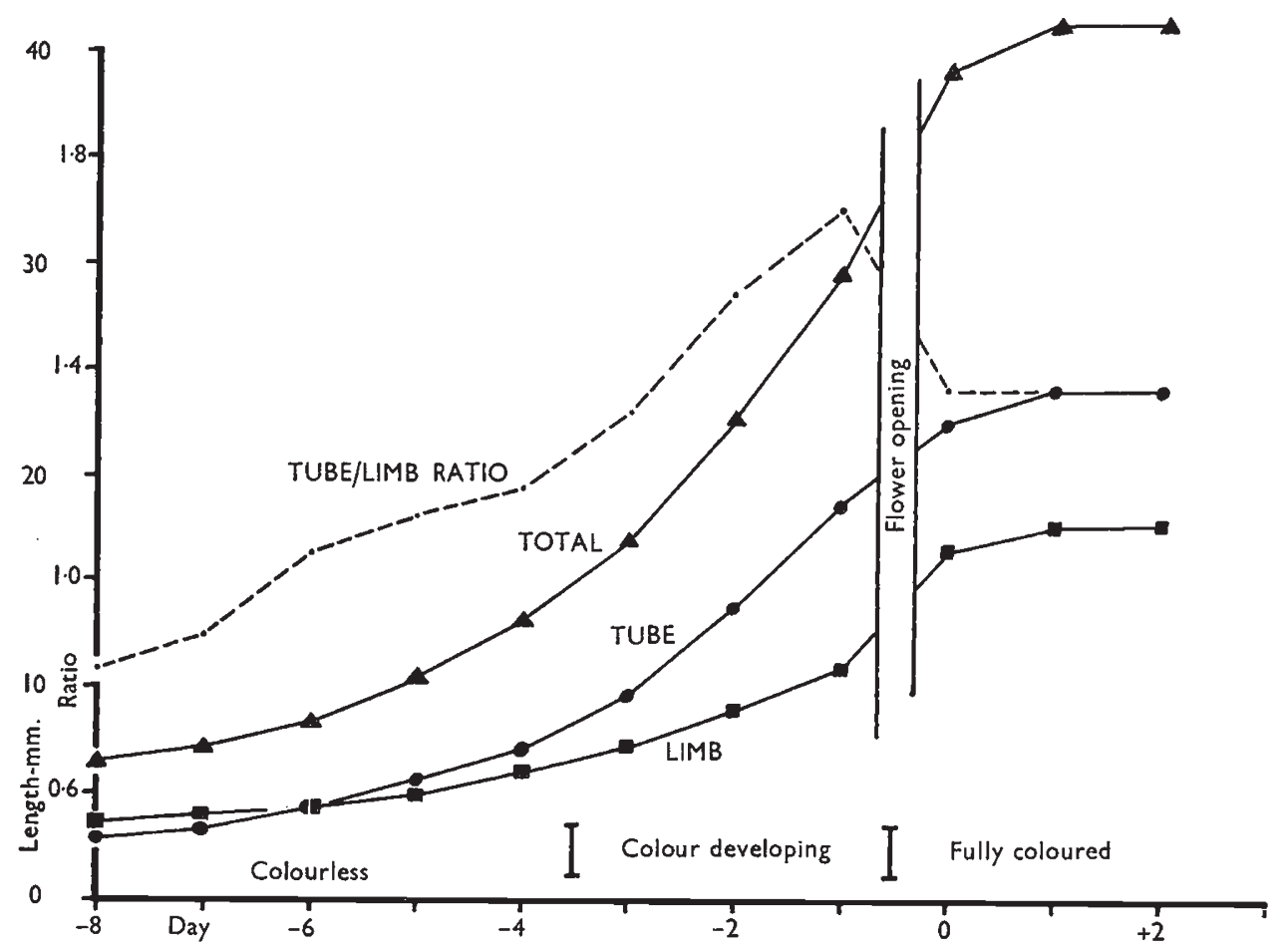

Fig. I.-The growth of flower buds of Lochnera rosea. Tube and limb length (mm.) and tube/limb ratio in relation to age.

in classification, very weak flushes grading imperceptibly to the $\mathrm{E}$ condition.

Pink flower colour appears to be correlated with a morphological character of the flower; the annulus that encloses a crater-like depression at the eye of the flower is, in $\mathrm{P}$ plants, less prominent than in other phenotypes and the inner boundary of pigmentation is correspondingly less sharply defined. The result is that the eyes of $\mathrm{P}$ flowers are less conspicuous and pigmentation appears to be more diffuse. This character was examined in only a small minority of the families discussed here and its significance cannot yet be assessed.

At a late stage in this work, the possibility was recognised that $\mathrm{E}$ and $\mathrm{F}$ flowers are not homogeneous but contain two distinct forms, 
one with pigment bluer in shade than the other. Search revealed that $\mathrm{E}$ plants could in fact be so classified, the bluer-toned form ( $\mathrm{Eb}$ in table I) owing its colour to copigmentation. All F plants seen were blue-toned ( $\mathrm{Fb}$ in table $\mathrm{I}$ ) but it seems virtually certain that red-toned ones (Fr) exist and may have segregated undetected in one family described below (table 2, line 8).

In order to establish a "morphological " time scale to aid the study of colour development, flowers were tagged as young buds and daily measurements of length of tube and limb were made. Results are summarised in fig. I in which it will be seen that the tube grows faster than the limb up to the day of flowering, the tube/limb ratio reaching a maximum of $I \cdot 7$ on the day before opening. At opening, and for one day after that, tube length continues to increase but the limb expands more rapidly and the ratio falls. Each flower lasts for two days, sometimes for three; there is no perceptible increase in size after the second day. Boke (1948, fig. 25) gives diagrams to illustrate flower development.

This established, I6o buds were measured, dissected and scored for colour development. The measurements yielded an estimate of age and the results are plotted in fig. 2. The colour scoring scale used was: o-no pigment; I-very faint eye colour; 2-medium eye colour; 3-strong eye colour; 4-strong eye, weak or partial lobe colour; 5-strong eye, full lobe colour. It will be seen from fig. 2 that $\mathrm{V}$ flowers, the most strongly pigmented at maturity, were distinctly faster to develop colour in the bud stage than other phenotypes; the least pigmented phenotype, E, was the slowest and the intermediate phenotypes, $\mathrm{F}$ and $\mathrm{P}$, developed at a similar rate, though $P$ finally exceeded $F$. All pigmented flowers, it will be noted, pass through a stage in which pigment is confined to the eye.

The chemical study of the pigments responsible for flower colour is little advanced and cannot be treated in detail here. Forsyth and Simmonds ( 1957) found that the bulk of the anthocyanin present was a glycoside of hirsutidin * which was accompanied by traces of glycosides of petunidin and malvidin. In $\mathrm{P}, \mathrm{E}$ and $\mathrm{F}$ phenotypes, the hirsutidin glycoside alone has been detected (though the other two may well have been present in low concentration). Three anthoxanthins also occur in the flowers. All three were detected in the lobes and/or eyes of $\mathrm{V}, \mathrm{P}, \mathrm{E}$ and $\mathrm{F}$ phenotypes and there was, to judge from visual examination of chromatograms, wide variation in their absolute and relative amounts. Copigmentation was found to be responsible for the blue tones of $\mathrm{V}$ and $\mathrm{Eb}$ flowers in comparison with $\mathrm{P}$ and $\mathrm{Er}$ (table $\mathrm{I}$ ). Differences between the colour of fresh extracts of coloured petals in I per cent. aqueous hydrochloric acid corresponded with differences between the living flowers. On boiling, the bluer solutions reddened but blued again on cooling, whereas the reddersolutions were unaffected.

* Strictly, of trimethyl delphinidin; the position of the methyl groups in the Lochnera pigment has not been proved though it seems likely, a priori, that they correspond in position with those of the Primula anthocyanidin. 
<smiles>C1CCC1</smiles> 


\section{GENETICAL RESULTS}

The stocks of periwinkle used in these experiments were probably all diploid and cytologically normal. Temporary PMC preparations in acetocarmine yielded the chromosome count, $n=8$, in agreement with the observation of Furusato (1940). No sterile plants or plants showing gigas characters suggestive of polyploidy were noted in any of the cultures.

In preliminary selfings of plants isolated vegetatively from local gardens, several hundred progeny were raised. All the parents proved to be true breeding (neglecting a very few evident rogue plants). At the St Augustine Nursery of the Trinidad Department of Agriculture,

\section{TABLE 2}

Segregations for flower colour in Lochnera rosea

\begin{tabular}{|c|c|c|c|c|c|c|c|c|c|c|}
\hline \multirow{2}{*}{\multicolumn{2}{|c|}{ Parentage }} & \multirow{2}{*}{$\mathrm{F}_{1}$} & \multicolumn{5}{|c|}{ Segregation in $F_{2}$} & \multirow{2}{*}{$\begin{array}{l}\text { Heterog. } \chi^{2} \\
\text { [D.f.] }\end{array}$} & \multirow{2}{*}{$\begin{array}{l}\text { Ratio } \\
\text { tested } \dagger\end{array}$} & \multirow{2}{*}{$\chi^{2}$ [D.f. $]$} \\
\hline & & & V & $\mathrm{P}$ & $\mathbf{E}$ & F & W & & & \\
\hline I. $\mathrm{V} \times \mathrm{P}^{*}$ & . & $\mathrm{V}$ & $26 r$ & 70 & $\cdots$ & $\cdots$ & $\cdots$ & $\cdots$ & $3: I$ & $2 \cdot 62[1]$ \\
\hline $\begin{array}{l}\text { 2. } V \times E \\
\text { 3. } V \times F^{*}\end{array}$ & . & $\begin{array}{l}\mathrm{V} \\
\mathrm{V}\end{array}$ & $\begin{array}{l}33 \\
62\end{array}$ & $\begin{array}{l}\cdots \\
\cdots\end{array}$ & $\begin{array}{r}14 \\
2\end{array}$ & $\ddot{20}$ & $\begin{array}{l}\cdots \\
\cdots\end{array}$ & $0 \cdot 20[\mathrm{I}]$ & $3: 1$ & $0.43[1]$ \\
\hline $\begin{array}{l}\text { 4. } V \times W(1) \\
\text { 5. } V \times W(2)\end{array}$ & . & $\begin{array}{l}\text { V } \\
\text { V }\end{array}$ & $\begin{array}{l}25 \\
65\end{array}$ & $\begin{array}{l}\cdots \\
\cdots\end{array}$ & $\begin{array}{l}\cdots \\
\cdots\end{array}$ & $\begin{array}{l}\cdots \\
\cdots\end{array}$ & $\begin{array}{l}21 \\
23\end{array}$ & $\begin{array}{l}\cdots \\
\cdots\end{array}$ & $\begin{array}{l}9: 7 \\
3: 1\end{array}$ & $\begin{array}{l}0.07[\mathrm{I}] \\
0.06[\mathrm{r}]\end{array}$ \\
\hline $\begin{array}{l}\text { 6. } \mathrm{P} \times \mathrm{E}(\mathrm{r}) * \\
\text { 7. } \mathrm{P} \times \mathrm{E}(2) \\
\text { 8. } \mathrm{P} \times \mathrm{F} *\end{array}$ & . & $\begin{array}{l}\mathrm{V} \\
\mathrm{V} \\
\mathrm{V}\end{array}$ & $\begin{array}{r}110 \\
14 \\
67\end{array}$ & $\begin{array}{r}32 \\
1 \\
14\end{array}$ & $\begin{array}{r}20 \\
7 \\
8\end{array}$ & $\begin{array}{l}\cdots \\
\cdots \\
18\end{array}$ & $\begin{array}{l}\cdots \\
\cdots \\
\cdots\end{array}$ & $\left\{\begin{array}{l}7 \cdot 62[2]^{*} \\
3.58[2]\end{array}\right.$ & $\begin{array}{l}9: 3: 4 \\
9: 3: 4 \\
9: 3: 4\end{array}$ & $\begin{array}{r}14 \cdot 37[2] * * * \\
2 \cdot 99[2] \\
2 \cdot 91[2]\end{array}$ \\
\hline 9. $\mathrm{P} \times \mathrm{W}^{*}$ & . & V & 135 & 48 & $\cdots$ & $\cdots$ & $5^{1}$ & $\cdots$ & $9: 3: 4$ & $\mathrm{I} \cdot 44[2]$ \\
\hline $\begin{array}{l}\text { го. } E \times W^{*} \\
\text { г г. } F \times W^{*}\end{array}$ & . & $\begin{array}{l}\mathrm{V} \\
\mathrm{V}\end{array}$ & $\begin{array}{l}\text { I } 3 \\
\text { I } 57\end{array}$ & $\begin{array}{l}\cdots \\
\cdots\end{array}$ & $\begin{array}{l}22 \\
18\end{array}$ & $\ddot{31}$ & $\begin{array}{l}33 \\
69\end{array}$ & $4 \cdot 56[2]$ & $9: 3: 4$ & $4 \cdot 18[2]$ \\
\hline 12. $E \times F^{*}$ & . & $E$ & $\cdots$ & $\ldots$ & 83 & 175 & $\cdots$ & $\cdots$ & $81: 175$ & $0.03[\mathrm{I}]$ \\
\hline
\end{tabular}

* These families were grown in reciprocal ; all were homogeneous.

$\dagger$ Combining $\mathrm{E}$ and $\mathrm{F}$ classes for purpose of analysis, except in bottom line (see text).

periwinkle plants are regularly raised in large numbers for public sale. It is nursery experience that $\mathrm{V}, \mathrm{P}, \mathrm{E}, \mathrm{F}$ and $\mathrm{W}$ stocks breed true year after year from open-pollinated seed (S. Bharath, personal communication). These observations, together with those of Boke (1949), make it clear that the periwinkle is fairly highly inbred.

Nineteen out of the twenty possible crosses involving five phenotypes $(\mathrm{V}, \mathrm{P}, \mathrm{E}, \mathrm{F}, \mathrm{W})$ were made and $\mathrm{F}_{1}$ and $\mathrm{F}_{2}$ results are summarised in table 2. For the purpose of preliminary analysis, $\mathrm{E}$ and $\mathrm{F}$ classes have been combined into one (referred as E-F) since they tend to intergrade and, as will be seen in table 2 , behaved in a similar fashion in combination with other phenotypes. 
The only aberrant family is the cross $\mathrm{P} \times \mathrm{E}$ (line 6) which showed a significant deficiency of $\mathrm{E}$ plants. Repetition of the cross gave the results summarised in line 7; these results are heterogeneous with the preceding but agree with the results of the parallel $\mathrm{P} \times \mathrm{F}$ cross (line 8) and with a theoretical $9: 3: 4$ ratio. From this $\mathrm{F}_{2}$ (i.e. $\mathrm{P} \times \mathrm{E}(2)-$ line 7), twenty-two small $F_{3}$ families were raised, with the following results. Of the $\mathrm{V}$ plants, two bred true (giving $32 \mathrm{~V}$ ), three segregated pinks $(2 \mathrm{IV}: 7 \mathrm{P})$ and nine segregated all three phenotypes $(52 \mathrm{~V}: 26 \mathrm{P}$ : ${ }_{24} \mathrm{E}-\chi^{2}[2]$ for $\left.9: 3: 4=3 \cdot 09\right)$; the single pink $\mathrm{F}_{2}$ plant segregated ${ }_{9} \mathrm{P}: 6 \mathrm{E}\left(\chi^{2}[\mathrm{I}]\right.$ for $\left.3: \mathrm{I}=\mathrm{I} \cdot 8 \mathrm{o}\right)$; and the seven $\mathrm{E}$ plants all bred true (giving $86 \mathrm{E}$ ). Two expected $\mathrm{F}_{2}$ genotypes were not recovered, namely a $\mathrm{V}$ plant segregating $3 \mathrm{~V}:$ I $\mathrm{P}$ and a true-breeding pink. These facts all agree with the hypothesis that two genes were segregating and interacting in such a way as to give a $9: 3: 4$ ratio in the $F_{2}$. There is no evidence of the occurrence of disturbance in segregation detected in the earlier $\mathrm{F}_{2}$ of the same percentage. It is concluded that the aberrant $\mathrm{F}_{2}$ family (line 6) suffered some viability disturbance that eliminated a proportion (about one-third) of the $\mathrm{E}$ plants.

The following scheme accounts for the main facts of colour determination in the periwinkle. The Symbols $W$ and $R$ are the same as those used by Flory (I944) since identity seems to be reasonably certain.

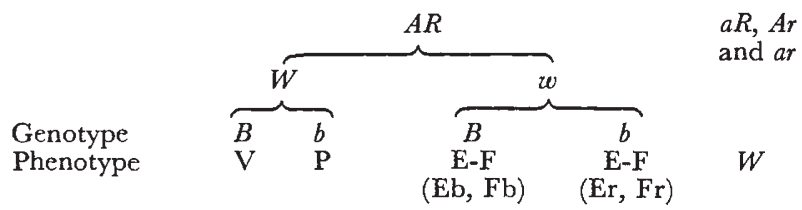

$A$ and $R$ are basic colour genes complementary in action.

$W$ is concerned with pattern, $W$ being wholly coloured, $w$ limiting pigment to the eye region.

$B$ is a copigmentation gene which blues the pigment in $W$ genotypes (probably also in ww-see below).

$W$ and $B$ are hypostatic to $A$ and $R$.

Although proof is lacking, E-F plants having been incompletely classified, it is likely that blue-toned $\mathrm{E}$ flowers (Eb of table I) bear to red-toned flowers $(\mathrm{Er})$ the same relation that $\mathrm{V}$ bears to $\mathrm{P}-$ i.e. they are copigmented by the action of $B$; this is indicated in brackets in the scheme above.

On this basis, the observed segregations are interpreted as follows:

\begin{tabular}{rcccc}
\multicolumn{1}{c}{ Cross } & $\begin{array}{c}\mathrm{F}_{1} \\
\text { phenotype }\end{array}$ & $\mathrm{F}_{1}$ genotype & $\begin{array}{c}\text { Loci } \\
\text { segregating }\end{array}$ & $\mathrm{F}_{2}$ ratio \\
$\mathrm{V} \times \mathrm{P}$ & $\mathrm{V}$ & $A R W B b$ & $B$ & $3 \mathrm{~V}:$ I \\
$\mathrm{V} \times \mathrm{E}-\mathrm{F}$ & $\mathrm{V}$ & $A R W w B$ & $3:$ I E-F \\
$\mathrm{V} \times \mathrm{W}(\mathrm{I})$ & $\mathrm{V}$ & $A a R W B$ or $A R r W B$ & $A$ or $R$ & $3 \mathrm{~V}: \mathrm{IW}$ \\
$(2)$ & $\mathrm{V}$ & $A a R r W B$ & $A R$ & $9 \mathrm{~V}: 7 \mathrm{~W}$ \\
$(3) *$ & $\mathrm{~V}$ & $A R r W w B$ & $R W$ & $9 \mathrm{~V}: 3 \mathrm{E}-\mathrm{F}: 4 \mathrm{~W}$ \\
$\mathrm{P} \times \mathrm{E}-\mathrm{F}$ & $\mathrm{V}$ & $A R W w B b$ & $W B$ & $9 \mathrm{~V}: 3 \mathrm{P}: 4 \mathrm{E}-\mathrm{F}$ \\
$\mathrm{P} \times \mathrm{W}$ & $\mathrm{V}$ & $A a R W B b$ or $A R r W B b$ & $A B$ or $R B$ & $9 \mathrm{~V}: 3 \mathrm{P}: 4 \mathrm{~W}$ \\
$\mathrm{E}-\mathrm{F} \times \mathrm{W}$ & $\mathrm{V}$ & $A a R W w B$ or $A R r W w B$ & $A W$ or $R W$ & $9 \mathrm{~V}: 3 \mathrm{E}-\mathrm{F}: 4 \mathrm{~W}$
\end{tabular}

\footnotetext{
* From Flory ; other entries from the present work.
} 
The results also suggest (though hardly prove) the nature of the genetic difference between $\mathrm{E}$ and $\mathrm{F}$ phenotypes. Flush crosses yielded in the $\mathrm{F}_{2}$ (data from table 2):

$\begin{array}{rrr}\text { Line } & \text { E } & \text { F } \\ 3 & 2 & 20 \\ 8 & 8 & 18 \\ 11 & 18 & 31 \\ 12 & 83 & \text { 175 }\end{array}$

These results obviously suggest that a system of complementary dominant genes control the restriction of pigment to the eye itself. If four independent loci were concerned, the expected ratio would be 81 : 175 and the figures homogeneously agree with this ratio:

\begin{tabular}{|c|c|c|c|}
\hline Item & $\chi^{2}$ & D.f. & $\mathrm{P}$ \\
\hline Deviation $(8 \mathrm{I}: \mathrm{I} 75)$ & 0.095 & $\mathrm{I}$ & $0 \cdot 7-0 \cdot 8$ \\
\hline Heterogeneity & $6 \cdot 387$ & 3 & $0 \cdot 1-0 \cdot 05$ \\
\hline
\end{tabular}

Most of the heterogeneity $\chi^{2}$ is contributed by the first entry in the table, in which there is a suggestive (though non-significant) deficiency of $\mathrm{E}$ plants. As a working hypothesis, therefore, it seems that the $\mathrm{F}$ stocks used were quadruply recessive (say $l m n o$ ) and that all the others tested were homozygous dominant at the same loci $(L M N O)$.

\section{CONCLUSIONS AND SUMMARY}

Four major genes control flower colour in Lochnera rosea. Two $(A$ and $R$ ) are basic complementary genes without both of which the flower is white. Coloured $(A R)$ genotypes are modified by $W$ and $B$, ww plants having pigment confined to the eye of the flower, $W$ flowers being fully coloured; $B$, by copigmentation, blues the pigment in an $A R W$ background, probably also in ARwre genotypes. An independent system of complementary dominants controls the distribution of pigment in eyed plants, variously restricting it to the eye region alone or permitting it to spread out onto the corolla limb. The result is that five main phenotypes may be recognised (Violet, Pink, Eye, Flush and White); probably, Eye and Flush colours could be classified as blue- or red-toned, making seven distinct phenotypes in all. The predominant anthocyanin present in pigmented flowers is a glycoside of hirsutidin (but see footnote p. 256) which is accompanied by anthoxanthins. Further chemical studies are required but it is clear that variation in flower colour is procured primarily by variation in rates of development and distribution of pigment and by copigmentation rather than by chemical variation in the pigment itself. Study of colour development shows that all flowers, even fully pigmented ones, pass through an "eyed" stage. This fact, the fact that eye colour is always much stronger than limb colour and the radial streakiness of colour in $\mathrm{E}$ and $\mathrm{F}$ phenotypes jointly suggest that the eye is the primary site of pigment synthesis and that the rate of production in and spread from this centre is controlled by $W$-w and by the complementary recessives that determine the Flush character. 


\section{REFERENCES}

ANDREWS, D. J. 1957. The inheritance of flower colour in Lochnera rosea. Thesis, I.C.T.A. (unpublished).

воKE, N. H. 1947. Development of the adult shoot apex and floral initiation in Vinca rosea L. Amer. 7. Bot., 34, 433-439.

воке, N. H. 1948. Development of the perianth in Vinca rosea L. Amer. F. Bot., $35,413-423$.

Boke, N. H. 1949. Development of the stamens and carpels in Vinca rosea L. Amer. 7. Bot., $36,535-547$.

FLORY, w. s. 1944. Inheritance studies of flower color in Periwinkle. Proc. Amer. Soc. hort. Sci., 44, 525-6.

FORSYTH, W. G. C., AND SIMMONDS, N. W. 1954. A survey of the anthocyanins of some tropical plants. Proc. Roy. Soc., B, $142,549-564$.

FORSYTH, w. G. C., AND SIMMONDS, N. w. 1957. Anthocyanidins of Lochnera rosea. Nature, Lond., $180,247$.

FURUSATO, K. I940. Polyploid plants produced by Colchicine. Bot. E Zool., 8, I303-131 I. [Not seen : cited by Darlington, C. D., and Wylie, A. P. I955. Chromosome Atlas of Flowering Plants. London.]

harborne, J. B. 1958. Anthocyanidins of the Primulaceæ. Nature, Loud., I8I, 26-27.

WAIT, A. W. 1956. Flower colour in Lochnera rosea. Thesis, I.C.T.A. (unpublished). WANSCHER, J. H. 1953. A simple way of describing flower colour and a flower colour chart. Roy. vet. agric. Coll., Copenhagen, Yearb., 91-104.

Note added in proof : for a recent discussion of the botany of this plant and for good line drawings, see Lawrence, G. H. M. (I959)-Baileya, 7, I13-9. Lawrence puts forward a strong argument for treating the species as a member of a genus distinct from Vinca under the name Catharanthus roseus (L.) G. Don. 